\title{
Waarom het Wetsvoorstel straffen en beschermen zijn doel voorbijschiet ${ }^{*}$
}

\author{
Sigrid van Wingerden
}

'Het is voor de samenleving, en voor slachtoffers in het bijzonder, onverteerbaar dat daders vrijwel altijd maar tweederde van de opgelegde straf achter de tralies zitten', aldus minister voor rechtsbescherming Dekker: 'Daar komt bij dat de zwaarst gestraften op die manier de langste periodes voorwaardelijk vrij zijn. Dit doet onvoldoende recht aan de straf die ze opgelegd hebben gekregen. ${ }^{1}$ Dekker heeft daarom op 15 januari jl. het Wetsvoorstel straffen en beschermen bij de Tweede Kamer ingediend. ${ }^{2}$ Dit wetsvoorstel bevat het voornemen om de regelingen over de detentiefasering en voorwaardelijke invrijheidstelling (v.i.) aan te passen. ${ }^{3}$

Het wetsvoorstel houdt onder meer in dat gevangenen voortaan niet meer vanzelfsprekend na twee derde van hun gevangenisstraf voorwaardelijk vrijkomen. In plaats daarvan gaat het Openbaar Ministerie (OM) van geval tot geval beslissen of een gedetineerde met v.i. mag. Die beslissing wordt gebaseerd op drie criteria: ten eerste het gedrag van de gevangene gedurende de hele detentie (waaruit moet blijken dat de gedetineerde bereid is om te werken aan een geslaagde terugkeer in de samenleving). Ten tweede hangt de beslissing over v.i. af van risico's; onder risico's worden het recidiverisico maar ook risico's voor slachtoffers, nabestaanden en eventuele andere personen verstaan. Het derde criterium voor de v.i.beslissing zijn de belangen van het slachtoffer en van de samenleving als geheel. Daarbij wordt ook gekeken naar inspanningen die de gevangene verricht heeft om de schade van het slachtoffer te vergoeden. ${ }^{4}$

* Mr. dr. Sigrid van Wingerden is als universitair docent Criminologie verbonden aan het Instituut voor Strafrecht \& Criminologie van de Universiteit Leiden. Zij is tevens voorzitter van de redactie van PROCES.

1 Nieuwsbericht Rijksoverheid d.d. 17 januari 2019, www.rijksoverheid.nl/actueel/nieuws/2019/ 01/17/voorwaardelijke-invrijheidstelling-naar-maximaal-2-jaar.

2 Kamerstukken II 2018/19, 35122, 2.

3 Niet alleen de v.i. wordt gewijzigd, ook de invulling van de gevangenisstraf wordt veranderd. Gedetineerden moeten actief aan de slag met een zogeheten detentie- en re-integratieplan. Gedragsverandering wordt gestimuleerd door inzet te belonen en negatief gedrag te bestraffen. Verlof is alleen nog mogelijk bij goed gedrag en dient gebruikt te worden voor een concreet reintegratiedoel, zoals het regelen van een legitimatiebewijs, onderdak, werk, zorg of grip op schulden (Nieuwsbericht Rijksoverheid d.d. 17 januari 2019, www.rijksoverheid.nl/actueel/nieuws/ 2019/01/17/voorwaardelijke-invrijheidstelling-naar-maximaal-2-jaar).

4 Kamerstukken II 2018/19, 35122, 3. 
De regelingen van de v.i. worden niet alleen aangepast voor wat betreft de individuele beslissingen door het OM, maar ook voor wat betreft de duur van de v.i. Deze blijft wel een derde van de duur van de opgelegde onvoorwaardelijke gevangenisstraf, maar nu met een maximum van 2 jaar. Dit heeft dus gevolgen voor straffen die langer dan zes jaar duren. Waar een gedetineerde die tot 12 jaar gevangenisstraf is veroordeeld nu na 8 jaar voorwaardelijk vrijkomt, moet hij met het nieuwe wetsvoorstel 10 jaar zitten voor hij vrij kan komen. Bij nog langere gevangenisstraffen wordt dit verschil nog groter: bij een gevangenisstraf van 30 jaar zal de gevangene niet na 20 jaar, maar pas na 28 jaar voor v.i. in aanmerking komen.

Het wetsvoorstel is in consultatie gegaan en diverse instanties hebben over het wetsvoorstel geadviseerd. Zorgen werden geuit over het nut en de noodzaak van een dergelijke ingrijpende wijziging in het Wetboek van Strafrecht. Zo werpt de Raad voor de rechtspraak de vraag op of de doelen die met v.i. beoogd worden wel beter worden bereikt met het wetsvoorstel. ${ }^{5}$ Vooral voor langgestraften betekent de wetswijziging dat een geleidelijke terugkeer in de samenleving niet goed meer mogelijk is, omdat pas twee jaar voor het einde van de straf kan worden begonnen met re-integreren in de samenleving. Dit kan te kort zijn voor een goede re-integratie als iemand al 16 jaar vastzit. De Raad van State waarschuwt in zijn advies zelfs dat dit het risico dat juist de zwaarste categorie veroordeelden vrijkomt zonder enige vorm van begeleiding, aanzienlijk vergroot. ${ }^{6}$ Bovendien wordt volgens de Raad van State de noodzaak tot de wetswijziging niet genoeg onderbouwd. ${ }^{7}$ Deze mening wordt gedeeld door de Raad voor Strafrechtstoepassing en Jeugdbescherming (RSJ), die aangeeft zich niet te kunnen vinden in de herziening omdat er geen aanwijzingen zijn dat de huidige regeling niet voldoet. ${ }^{8}$

In de financiële paragraaf van de memorie van toelichting wordt ervan uitgegaan dat de wetswijziging een gevolg heeft voor de omvang van de gevangenispopulatie: deze zal toenemen doordat langgestraften langer vast zitten voordat ze voor v.i. in aanmerking komen. ${ }^{9}$ Daar komt volgens het OM nog bij dat er langgestraften voor ernstige delicten zullen zijn die die twee jaar liever gewoon uitzitten dan dat ze v.i. krijgen met een proeftijd die telkens verlengd kan worden. ${ }^{10}$

Ik vraag me af of de wetswijziging zich rechtstreeks vertaalt in vollere gevangenissen. Dat is immers alleen maar zo als rechters hun straftoemetingspraktijk niet veranderen. En het lijkt mij sterk dat een rechter die nu bijvoorbeeld 18 jaar gevangenisstraf oplegt, in de wetenschap dat dat feitelijk 12 jaar 'zitten' betekent, na de inwerkingtreding van de wet blind zou zijn voor het feit dat hij dan met een straf van 18 jaar feitelijk 16 jaar oplegt en dat die straf dus zwaarder is. Zou een rechter zijn 'bruto straf' niet aanpassen opdat de 'netto straf' gelijk blijft? Wat levert deze hele wetswijziging dan op? Kortere bruto straffen, gelijke netto straffen, maar veel minder mogelijkheden tot re-integratie voor langgestraften. Dat

5 Advies Raad voor de rechtspraak, bijlage bij Kamerstukken II 2018/19, 35122, 3.

6 Kamerstukken II 2018/19, 35122, 4.

$7 \quad$ Kamerstukken II 2018/19, 35122, 4.

8 Advies RSJ, bijlage bij Kamerstukken II 2018/19, 35122, 3.

9 Kamerstukken II 2018/19, 35122, 3.

10 Advies OM, bijlage bij Kamerstukken II 2018/19, 35122, 3. 
lijkt mij nergens een oplossing voor en het maatschappelijk draagvlak voor de strafpraktijk zal er ook niet door toenemen: het Wetsvoorstel straffen en beschermen schiet daarmee zijn doel voorbij.

Dit nummer van PROCES vangt aan met een peer reviewed bijdrage van Janne van Doorn en Jelle Brands over het vertrouwen van jongeren in toezichtsactoren in het stedelijke nachtleven, waar toezichtstaken van de politie steeds vaker worden overgedragen op andere actoren, zoals portiers en camera's. De resultaten tonen aan dat het vertrouwen in de politie groter is dan het vertrouwen in portiers. Cameratoezicht wordt het minst vertrouwd. De mate van vertrouwen hangt af van kenmerken van de respondent, zoals geslacht, migratieachtergrond en slachtofferschap. Van Doorn en Brands wijzen er daarom op dat er in de toepassing van toezichtsactoren goed nagedacht moet worden met welk doel, en voor welke groep, het toezicht ingezet wordt, ook omdat een avondje stappen niet leuker wordt van buitensporig toezicht.

Vervolgens toetst Victor Huurman in hoeverre de bestuursrechtelijke Educatieve Maatregel Gedrag en verkeer (EMG) als een criminal charge moet worden gekwalificeerd. Hij meent dat de rechtsbescherming in het huidige stelsel onvoldoende is, gezien het punitieve karakter van de EMG en vanwege het feit dat een politieagent de verkeersdeelnemer aanmeldt bij het Centraal Bureau Rijvaardigheidsbewijzen (CBR), maar het CBR geen rekening kan houden met de individuele omstandigheden van het geval. De wetgever wordt opgeroepen in actie te komen. In de volgende bijdrage vergelijkt Charmaine Purperhart de rechtspositie van jongeren in gesloten jeugdinrichtingen in Nederland en België. Ondanks de verschillen (België kent geen jeugdstrafrecht) signaleert Purperhart ook overeenkomsten. Zo staan zowel in Nederland als in België de rechtspositieregelingen voor de jongeren op gespannen voet met de Europese wet- en regelgeving. Purperhart doet enkele aanbevelingen om de rechtspositie van ingesloten jeugdigen in Nederland te versterken.

Mark Westerlaken vertelt in zijn PROCESperikel hoe zijn werk als tatoeëerder wonderwel samengaat met zijn werk als operationeel specialist bij het Landelijk Expertise Centrum Eer Gerelateerd Geweld (LEC EGG) van de politie. Zo kunnen tatoeages bij slachtoffers van loverboys door opsporingsdiensten als gegevensdrager worden beschouwd.

Het artikel van Merijne Groeneweg en Harmen van den Dorpel biedt een kijkje achter de schermen bij een pro justitia onderzoek in Teylingereind. Zij laten aan de hand van vier casussen zien wat er gedaan kan worden om toch een advies aan de rechter te kunnen uitbrengen als jongeren weigeren om mee te werken aan delen van het onderzoek. Zo kan informatie uit het milieuonderzoek samen met informatie uit de observatieperiode diagnostisch worden gewogen door psychiater en psycholoog - ook wanneer zij niet over uitgebreid gespreksonderzoek beschikken. De klinische observatie kan zo van toegevoegde waarde zijn voor de rechter wanneer er ernstige zorgen bestaan omtrent de ontwikkeling van een jongere die weigert inzage te geven in zijn persoon.

In het laatste artikel bespreekt Tom Huisjes het Europees Openbaar Ministerie (EOM), dat vanaf eind 2020 operationeel zal zijn. Huisjes zet daarbij de achter- 
grond, de structuur en de bevoegdheden van het EOM uiteen. Vervolgens kijkt hij kritisch naar de bescherming van de fundamentele rechten van verdachten onder het EOM en het probleem van 'forumshopping voor bewijs'.

Dit nummer van PROCES sluit zoals gewoonlijk af met een PS van een redacteur, deze keer Coosje Peterse. Zij was onlangs aanwezig op het Crimefest, een 'festival' over de aanpak van (zware) jeugdcriminaliteit. Daar werd de stelling 'Criminaliteit is een keuze' verdedigd. De heftige reacties uit het publiek gaven aan dat veel mensen dat anders zien als het om kinderen gaat. 